\title{
A Case Study to Estimate the Greenhouse-Gas Mitigation Potential on Conventional Rice Production System
}

\author{
Jong-Hee Ryu*, Jong-Sik Lee, Kye-Hoon Kim', Gun-Yeob Kim, and Eun-Jung Choi \\ National Academy of Agricultural Science, RDA, Suwon, 441-707, Korea \\ ${ }^{1}$ Department of Environmental Horticulture, The University of Seoul, Seoul 130-743, Korea
}

(Received: October 7 2013, Accepted: November 22 2013)

To estimate greenhouse gas (GHG) emission, we established inventory of conventional rice cultivation from farmers in Gunsan and Iksan, Jeonbuk province in $2011 \sim 2012$. This study was to calculate carbon footprint and to analyse the major factor of GHGs. We caried out a sensitivity analysis using the analyzed main factors of GHGs and estimated the mitigation potential of GHGs. Also we tried to suggest agricultural methods to reduce GHGs that farmers of this case study can apply. Carbon footprint of rice production unit of $1 \mathrm{~kg}$ was $2.21 \mathrm{~kg} \mathrm{CO}_{2}$.eq. $\mathrm{kg}^{-1}$. Although amount of $\mathrm{CO}_{2}$ emissions is largest among GHGs, methane had the highest contribution of carbon footprint on rice production system after methane was converted to carbon dioxide equivalent $\left(\mathrm{CO}_{2}\right.$-eq.) multiplied by the global warming potential (GWP). Source of $\mathrm{CO}_{2}$ in the cultivation of rice farming is incomplete combustion of fossil fuels used by agricultural machinery. Most of the $\mathrm{CH}_{4}$ emitted during rice cultivation and major factor of $\mathrm{CH}_{4}$ emission is flooded paddy field in anaerobic condition. Most of the $\mathrm{N}_{2} \mathrm{O}$ emitted from rice cultivation process and major sources of $\mathrm{N}_{2} \mathrm{O}$ emission is application of fertilizer such as compound fertilizer, urea, orgainc fertilizer, etc. As a result of sensitivity analysis due to the variation in energy consumption, diesel had the highest sensitivity among the energies inputs. If diesel consumption is reduced by $10 \%$, it could be estimated that $\mathrm{CO}_{2}$ potential reduction is about $2.5 \%$. When application rate of compound fertilizer reduces by $10 \%$, the potential reduction is calculated to be approximately $1 \%$ for $\mathrm{CO}_{2}$ and approximately $1.8 \%$ for $\mathrm{N}_{2} \mathrm{O}$. When drainage duration is decreased until 10 days, methane emissions is reduced by approximately $4.5 \%$. That is to say drainage days, tillage, and reducing diesel consumption were the main sources having the largest effect of GHG reduction due to changing amount of inputs. Accordingly, proposed methods to decrease GHG emissions were no-tillage, midsummer drainage, etc.

Key words: Carbon footprint, LCA, Conventional rice farming, GHG reduction

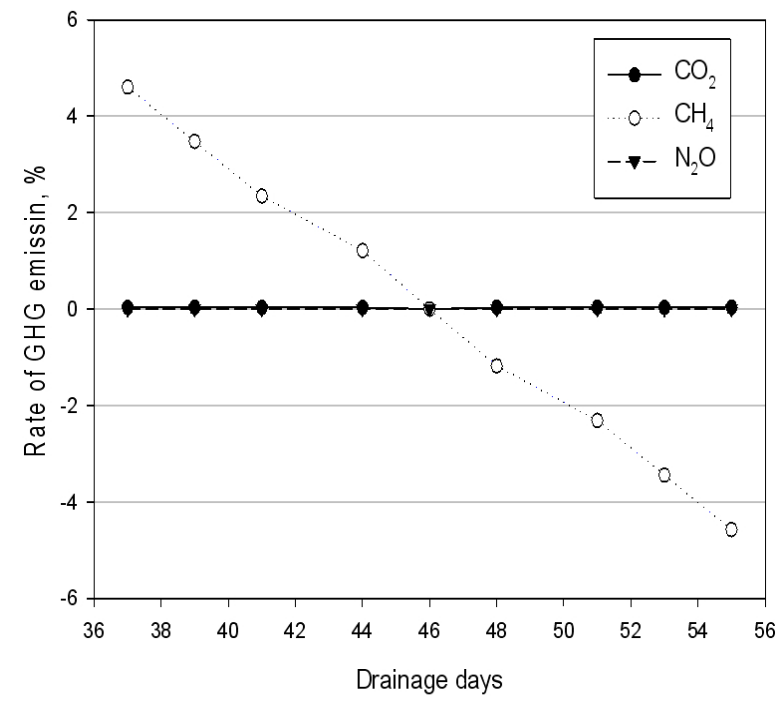

When drainage duration is decreased until 10 days, methane emissions is reduced by approximately $4.5 \%$

*Corresponding author : Phone: +82312900243, Fax:+82312900206, E-mail: soil73@kg21.net

${ }^{\S}$ Acknowledgement: This work was partially supported by the research grant of RDA in 2013. 


\section{Introduction}

우리나라는 2008년 녹색성장국가 비전을 선포하고 지구 온난화 문제 해결에 동참하는 방안으로 녹색성장정책을 추 진하고 있다. 기후변화대응과 녹색성장의 근간은 효율적 에 너지 이용 및 소비절감을 통한 온실가스 배출저감이다. 온 실가스 배출저감 수단으로써 직접적 규제정책의 예는 2012 년부터 시작된 '온실가스·에너지 목표 관리제'가 있다 (Shin and Park, 2011). 농업분야에서 시작된 온실가스 감축을 위 한 정책도입으로는 2013년 시범사업으로 시작된 '저탄소 농 축산물 인증제'가 있다. 이 제도는 농축산물 산출 과정에서 온실가스 저감이 인정되는 농법이 적용된 산물에 저탄소 인 증을 부여하는 시장을 기반으로 한 온실가스 감축 프로그램 이다 (Ryu et al., 2012).

농업분야는 전 세계 온실가스 배출량 중 약 10 20\%를 차 지하는 온실가스 배출 원이다 (Lehugera et al., 2011; Smith et al., 2007). 농업분야에서 온실가스 배출의 주요 인자는 직접적 배출과 간접적 배출로 나눌 수 있다. 직접배출은 농 작물 재배 중 토지이용을 통하여 배출되는 것이고, 간접배 출은 농자재 투입물 (비료, 농약 등)의 생산과정에서 배출되 는 온실가스 및 농기계 사용에 의한 연료연소 등이다. 농업 분야에서 탄소 배출을 줄이고 토양탄소 저장을 늘리는 연구 가 계속되고 있다. 그 동안의 연구결과로 추천되고 있는 탄 소배출 저감을 위한 대표적인 농작업에는 무경운, 바이오 에너지 작물, 녹비 시용, 벼논 물관리 등이 있다 (Bhatia et al., 2005; Lehugera et al., 2011; Mosier et al., 2005; Robertson et al., 2004).

본 연구에서는 전북지역 관행농 쌀을 생산하는 농가를 대상으로 하는 전과정평가 사례연구를 통하여 온실가스 배 출의 주요인을 분석하고, 탄소배출 감소 잠재량을 산출하여 대상지역 농가들이 적용할 수 있는 효과적인 온실가스 저감 영농법을 제안하고자 하였다.

\section{Materials and Methods}

연구 대상 본 연구는 2011년과 2012년 전북 군산과 익 산 지역의 관행농 쌀 재배 농가를 대상으로 쌀 생산 과정 중 투입·배출되는 물질 목록을 현장에서 면접 조사한 2년 누적
평균량을 구하여 탄소배출량 산정을 위한 인벤토리를 목록 을 구축하였다. 벼 재배 농가의 2011년 10 a당 평균 쌀 (조 곡) 수확량은 $742 \mathrm{~kg}$ 였고 2012년은 수해로 인해 평균생산량 이 줄어들어 수확량은 $679 \mathrm{~kg}$ 였다. 조사농가들이 재배하는 품종은 '신동진벼'였다 (Table 1).

연구 목적 및 범위 본 연구의 목적은 쌀 생산체계에 대한 탄소배출량 산정 및 온실가스 감축 잠재량 산정으로 정의하였다. 본 연구의 연구대상 산출물인 쌀의 기능은 식 용 및 각종 식품제조의 원료이며, 기능 단위는 식품 및 식품 제조의 원료용으로 사용되는 쌀 (조곡) $1 \mathrm{~kg}$ 생산으로 정의 하였다.

연구 범위는 쌀 생산체계에 대한 전과정을 생산 전 (前) 단계, 생산단계, 생산 후 (後) 및 폐기단계로 나누어 정의하 였다. 생산 전 단계는 벼 재배에 투입되는 농자재 및 비료, 농약, 에너지 등을 생산하는 공정이 포함된다. 생산단계는

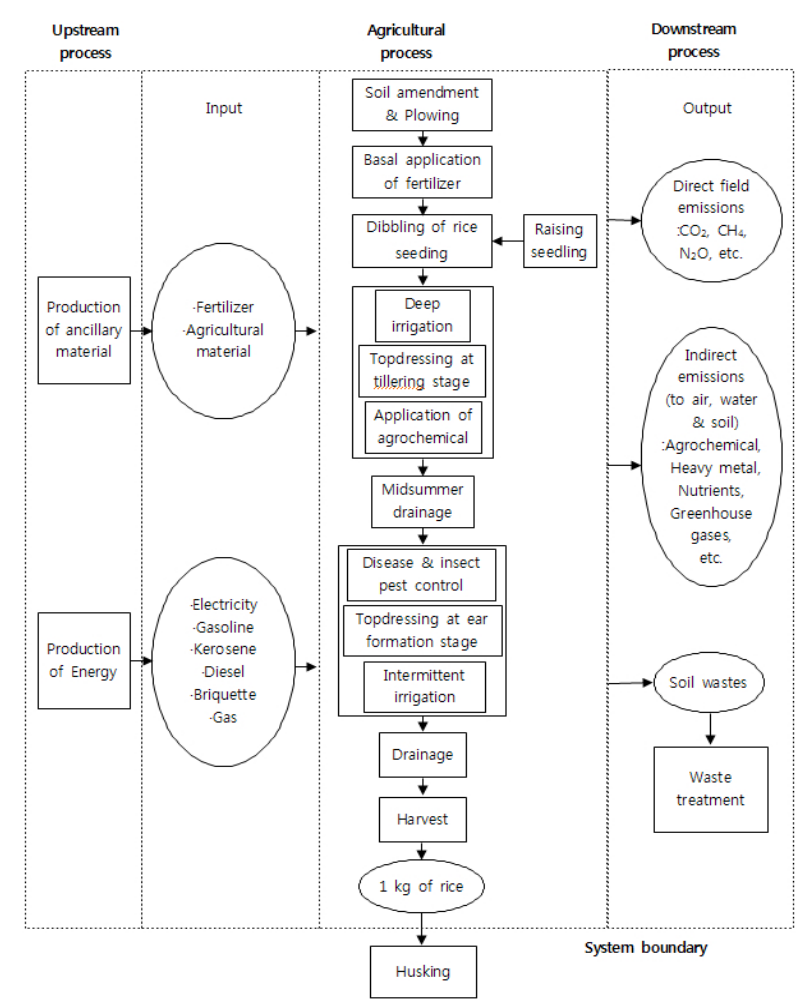

Fig. 1. System boundaries for conventional rice production system.

Table 1. Information of collected data for conventional rice cultivation.

\begin{tabular}{lcc}
\hline \multicolumn{1}{c}{ Item } & 2011 & 2012 \\
\hline Location & Jeonbuk Gunsan & Jeonbuk Gunsan \& Iksan \\
No. of research subjects & 4 & 9 \\
Total cultivation area (ha) & 13.3 & 31.2 \\
Cultivation periods (days) & 139 & 138 \\
Mean Yield (kg 10a-1) & 742 & 679 \\
Rice variety & 'Shindongjin' & 'Shindongjin' \\
\hline
\end{tabular}


육묘부터 벼 수확 (조곡생산)까지로 농가에서 이루어지는 쌀 생산관련 일련의 농작업 과정을 포함하며, 주로 지역 미 곡처리장에서 작업하는 도정작업과 수송과정은 연구범위에 서 제외되었다. 생산 후 단계는 벼 재배단계에서 배출되는 온실가스 (직접배출물) 산정과 생산 전단계를 포함하는 쌀 생산 전과정에서 배출되는 간접배출물 (수계, 대기, 토양)량 및 투입된 농자재들의 폐기물 처리단계를 포함한다 (Fig. 1).

전과정 목록분석 모든 투입·산출량 자료는 벼논 $10 \mathrm{a}$
를 기준으로 수집하였다. 질소투입량 및 농약 투입량은 현 장 방문하여 수집한 활동자료를 사용하였다 (Table 2, 3).

질소질 비료에 의한 벼논 아산화질소 발생량은 비료 투 입량 내 질소 유효성분함량에 배출계수는 IPCC 1996 Tier 1 배출계수 값을 곱하여 산정하였다 (Ryu et al., 2011). 메탄 배출량은 재배면적에 IPCC 1996 Tier 1값을 적용하고 유기 물시용 및 담수의 유·무와 재배일수 및 담수일수를 변수로 하여 산출하였다 (Jeong et al., 2011).

농약투입량은 조사된 사용량을 유효성분별로 계통분류한

Table 2. Inventories of fertilizer inputs for conventional rice cultivation.

\begin{tabular}{|c|c|c|}
\hline Entries of fertilizer & Mean of input amount ('11 '12 yr) & Linked upstream inventory DB \\
\hline \multicolumn{3}{|c|}{--- $\operatorname{kg~} 10 \mathrm{a}^{-1}$} \\
\hline Compost & 6.61E-01 & $\mathrm{RDA}^{\dagger}$ \\
\hline Mixed Expeller Cake & 4.95E-02 & $\mathrm{RDA}$ \\
\hline Compound fertilizer 21-13-9 & $9.91 \mathrm{E}-03$ & RDA \\
\hline Compound fertilizer $22-10-8$ & 1.64E-02 & RDA \\
\hline Compound fertilizer $17-10-7$ & $1.78 \mathrm{E}-02$ & $\mathrm{RDA}$ \\
\hline Compound fertilizer $17-0-7$ & $2.42 \mathrm{E}-03$ & RDA \\
\hline Compound fertilizer $21-17-17$ & $1.54 \mathrm{E}-02$ & RDA \\
\hline Compound fertilizer $20-10-11$ & 4.95E-03 & RDA \\
\hline Silicate fertilizer & $1.65 \mathrm{E}-01$ & RDA \\
\hline
\end{tabular}

${ }^{\dagger}$ RDA: Rural Development Administration.

Table 3. Inventories of agrochemical inputs for conventional rice cultivation.

\begin{tabular}{clc}
\hline \hline Entries of agrochemical & \multicolumn{1}{c}{$\begin{array}{c}\text { Associated chemical class with ecoinvent } \\
\text { (linked upstream inventory DB) }\end{array}$} & $\begin{array}{c}\text { Mean of input amount ('11 ‘12 yr) } \\
\text { Germicide }\end{array}$ \\
& \multicolumn{1}{c}{--- Active ingredient --- $10 \mathrm{a}^{-1}---$} \\
& (thio)Carbamate-compounds & $1.54 \mathrm{E}-05$ \\
& Cyclic N-compounds & $5.78 \mathrm{E}-07$ \\
& Pesticide unspecified & $6.20 \mathrm{E}-05$ \\
\hline \multirow{3}{*}{ Insecticide } & (thio)Carbamate-compounds & $9.91 \mathrm{E}-06$ \\
& Organophosphorus-compounds & $5.53 \mathrm{E}-06$ \\
& Pesticide unspecified & $9.27 \mathrm{E}-05$ \\
\hline \multirow{3}{*}{ Herbicide } & (sulfonyl)Urea-compounds & $1.30 \mathrm{E}-05$ \\
& (thio)Carbamate-compounds & $6.61 \mathrm{E}-06$ \\
& Diphenylether-compounds & $1.45 \mathrm{E}-05$ \\
& Pesticide unspecified & $2.47 \mathrm{E}-05$ \\
\hline
\end{tabular}

Table 4. Inventories of energy and agricultural material inputs.

\begin{tabular}{lcc}
\hline \hline \multicolumn{1}{c}{ Entries of inputs inventories } & Mean of input amount ('11 '12 yr) & Linked upstream inventory DB \\
\hline & $-1 \mathrm{~kg} 10 \mathrm{a}^{-1}--$ & \\
Energy & $9.85 \mathrm{E}-03$ & $\mathrm{MKE}^{\dagger}$ \\
Electricity (Kwh $\left.10 \mathrm{a}^{-1}\right)$ & $2.63 \mathrm{E}-02$ & $\mathrm{MKE}$ \\
Diesel & $1.28 \mathrm{E}-02$ & $\mathrm{MKE}$ \\
Kerosene & $4.56 \mathrm{E}-03$ & $\mathrm{MKE}$ \\
Gasoline & & \\
Agricultural materials & $8.45 \mathrm{E}-03$ & $\mathrm{RDA}^{\ddagger}$ \\
Lagging cover (Non-woven fabric)
\end{tabular}

${ }^{\dagger}$ MKE: Ministry of Knowledge Economy, Republic of Korea; ${ }^{\ddagger}$ RDA: Rural Development Administration. 
유효성분함량을 투입량으로 산정하였다. 에너지 및 농자재 투입에 대한 자료 수집은 Table 4에 나타냈다. 농작업 중 연 료사용으로 배출되는 온실가스 $\left(\mathrm{CO}_{2}, \mathrm{CH}_{4}, \mathrm{~N}_{2} \mathrm{O}\right)$ 산정은 IPCC 1996 Tier 1 배출계수를 적용하였다 (Ryu et al., 2011). 농 자재 폐기물량은 현장 수집자료를 활용하되, 폐기물처리는 환경자원공사와 농림수산식품부의 영농폐기물 통계 (KWA, 2007, MIFAFF, 2004) 자료를 사용하였다 (Table 5).

전과정 목록분석을 위하여 지식경제부에서 보급하는 전 과정평가 수행 프로그램 PASS (v.4.1.3)를 사용하였고, 상. 하위 흐름 $\mathrm{DB}$ 는 환경부, 지경부, 현재 국립농업과학원에 구 축 중인 농자재 $\mathrm{DB}$ 등 국내자료를 우선 적용하고, 국내 $\mathrm{DB}$ 가 없는 농약의 경우 ecoinvent $\mathrm{DB}$ 를 사용하였다 (MKE: Ministry of Knowledge Economy methodology, Software program PASS v4.1.3). 탄소성적 산정은 전과정 목록분석결과 산출 된 교토의정서 규정 6 대 온실가스 $\left(\mathrm{CO}_{2}, \mathrm{CH}_{4}, \mathrm{~N}_{2} \mathrm{O}, \mathrm{HFCs}\right.$, $\mathrm{SF}_{6}, \mathrm{PFCs}$ ) 배출량에 지구온난화지수 (Global warming potential, $\mathrm{GWP})$ 를 곱하여 이산화탄소 당량 $\left(\mathrm{kg} \mathrm{CO}_{2}\right.$ eq. $\left.\mathrm{kg}^{-1}\right)$ 으로 정 량화하였다 (Ryu et al., 2011).

전과정 영향평가 전과정 목록분석 결과를 6 범주로 구 분하고 지식경제부 영향평가 방법론의 특성화계수 및 특성 화 모델을 적용하여 (Table 6), 각 범주별 기준물질 대한 관 련 물질들의 상응값 (특성화 계수)과 발생량을 곱하여 영향 범주별 환경영향 기여도를 평가하였다 (Ryu et al., 2011). 영향범주는 무생물자원고갈 (ADP), 지구온난화 (GWP), 오 존층고갈 $(\mathrm{ODP})$, 산성화 $(\mathrm{AP})$, 부영양화 $(\mathrm{EP})$, 광화학산화
물생성 (POCP) 등이고, PASS 4.1.3. 프로그램을 사용하여 전과정 여향평가를 수행하였다 (MKE: Ministry of Knowledge Economy methodology, Software program PASS v4.1.3).

민감도 분석 민감도 분석은 전과정 목록분석 및 영향 평가 단계에서 할당방법, 투입데이터의 불확실성 및 가정 등이 분석결과에 미치는 영향을 분석하는데 사용된다 (Ahn, 2005). 민감도 분석은 비료와 에너지 등의 투입량 변화가 온실가스 발생에 어떠한 영향을 주는지 알아보기 위하여 공 정기여도를 1 로 하여 각각 사용량이 $-20 \sim 20 \%$ 까지 $5 \%$ 간격 으로 변할 때의 온실가스 발생 변화량을 구하였다.

가정 및 제한사항 본 연구에서 국립농업과학원에서 개 발 중인 전과정평가법에 준하여 농기계 제조 및 시설 (육묘 용 하우스 및 저장시설 등) 구축, 운송에 따른 환경부하는 고려하지 않고, 물리적인 투입·배출물만 정량화하였다. 비 료포대 등 원부자재 포장에 대한 환경부하는 고려하지 않 았고, 대상 시스템에서 발생한 부산물 (볏짚 등)은 기술계 (technosphere)로부터 투입된 물질들의 배출이 아닌 자연적 인 물질순환의 일부로 시스템 내부에서 다시 분해된다고 가 정하였다 (van Zeijts et al., 1999).

\section{Results and Discussion}

탄소배출량 산정 및 기여도 평가 전과정 목록분석 결 과 $\mathrm{CO}_{2}$ 배출은 화학비료 생산과 벼 재배단계에서 가장 많았

Table 5. Inventories of product (rice) and outputs.

\begin{tabular}{lcc}
\hline \hline Entries of outputs inventories & Mean of input amount ('11 ‘'12 yr) & Linked outstream inventory DB \\
\hline $\begin{array}{l}\text { Direct field emission } \\
\left(\mathrm{GHGs}: \mathrm{CO}_{2}, \mathrm{CH}_{4}, \mathrm{~N}_{2} \mathrm{O}\right)\end{array}$ & $---\mathrm{kg} 10 \mathrm{a}^{-1}----$ & - \\
Waste & $2.11 \mathrm{E}-01$ & $\mathrm{ME}^{\dagger}$ \\
$\quad$ Lagging cover wastes & $1.64 \mathrm{E}-03$ & - \\
Product \\
$\quad$ Rice (unhulled)
\end{tabular}

Table 6. Impact categories in life cycle impact assessment (LCIA).

\begin{tabular}{lll}
\hline \multicolumn{1}{c}{ Impact categories } & \multicolumn{1}{c}{ Unit } \\
\hline ADP & $1 \mathrm{yr}^{-1}$ & CIA, International Energy Annual 2000, USGS 2001 2002 \\
GWP & $\mathrm{kg} \mathrm{CO}$-eq. kg & Characterization models \\
ODP & $\mathrm{kg} \mathrm{CFC}$-eq. $\mathrm{kg}^{-1}$ & IPCC 1996 (100 year) \\
$\mathrm{AP}$ & $\mathrm{kg} \mathrm{SO}$-eq. kg & UNEP 2002 \\
EP & $\mathrm{kg} \mathrm{PO}{ }^{-1}$-eq. $\mathrm{kg}^{-1}$ & $\mathrm{CML} \mathrm{1999,} \mathrm{Hauschild} \mathrm{\&} \mathrm{Wenzel,} \mathrm{1998}$ \\
POCP & $\mathrm{kg} \mathrm{C} \mathrm{H}_{4}$-eq. $\mathrm{kg}^{-1} \mathrm{~kg}^{-1}$ & Heijungs et al. 1992 \\
\hline
\end{tabular}

${ }^{\dagger}$ ADP, Abiotic resource Depletion; GWP, Global Warming Potential; ODP, Ozone Depletion Potential; AP, Acidification Potential; EP, Eutrophication Potential; POCP, Photochemical Ozone Creation Potential. 


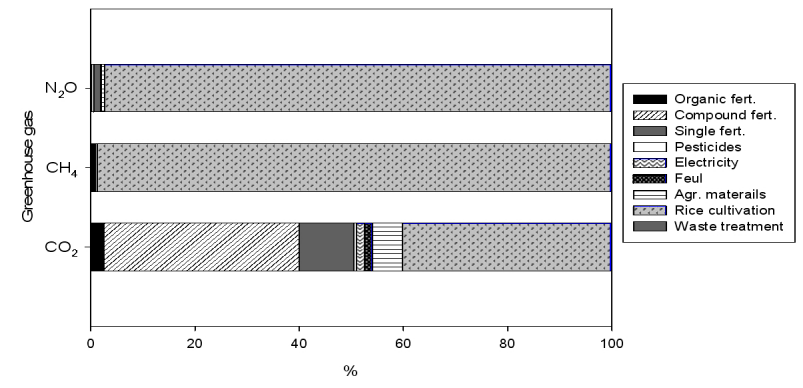

Fig. 2. Contribution rate of the process of conventional rice production to Greenhouse gas emission.

다. 전체 $\mathrm{CO}_{2}$ 배출량 중 복비생산 공정에서 $37 \%$ 가 발생하였 고, 단비생산으로 $10 \%$, 벼 재배과정에서 $40 \%$ 가 발생하였 다. 벼 재배 중 $\mathrm{CO}_{2}$ 발생원은 농기계의 화석연료 사용에 의 한 불완전 연소이다. Koga et al. (2003)의 연구결과에서도 작물재배 중 $\mathrm{CO}_{2}$ 배출 주요인은 농기계 작업에 의한 $\mathrm{CO}_{2}$ 배 출이었고, 특히 연료사용이 가장 많은 경운과 수확작업이 $\mathrm{CO}_{2}$ 배출 주요인자였다. $\mathrm{CH}_{4}$ 는 대부분 벼 재배 중에 발생되 었으며, 벼논의 메탄 발생 요인은 혐기조건의 담수논이다. $\mathrm{N}_{2} \mathrm{O}$ 은 대부분 벼 재배과정에서 배출되었고, 벼 재배 중 $\mathrm{N}_{2} \mathrm{O}$ 의 발생요인은 복비, 요소 비료, 퇴비 등의 비료 시용이 었다 (Fig. 2).

쌀 생산체계에서 전체 온실가스 배출량을 탄소성적으로 환산한 결과 쌀 $1 \mathrm{~kg}$ 생산할 때 $2.21 \mathrm{~kg} \mathrm{CO}-$-eq. $\mathrm{kg}^{-1}$ 가 발 생되었다. 온실가스 중 $\mathrm{CO}_{2}$ 배출량이 가장 많았으나, 지구 온난화 지수를 곱하여 이산화탄소 등가 $\left(\mathrm{CO}_{2}-\mathrm{eq}.\right)$ 로 환산하 면 벼 생산체계의 탄소성적 산정에서 메탄발생 비중이 가장 컸다. 일반적으로 밭작물의 재배에서는 시설재배는 $\mathrm{CO}_{2}$ 가 노지재배는 $\mathrm{N}_{2} \mathrm{O}$ 의 비중이 크게 나타나지만 (Kramer et al., 1999), 담수조건의 벼논에서는 메탄발생량이 증가하면서 $\mathrm{CH}_{4}$ 의 탄소성적 비중이 가장 크게 나타났다 (Table 7). 따라서 논벼 재배에서 논물관리는 온실가스 감축을 위한 주요인자 로 판단되었다.

전과정 영향평가 환경영향범주별 쌀 생산 체계의 환 경영향 기여도 분석 결과 벼 작물 재배로 가장 큰 영향을 받

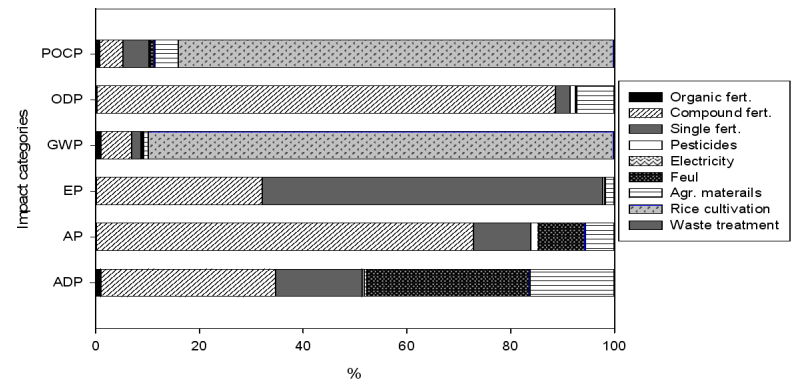

Fig. 3. Contribution of conventional rice system to environment impacts (ADP: Abiotic resource Depletion Potential; GWP: Global Warming Potential; ODP: Ozone Depletion Potential; AP: Acidification Potential; EP: Eutrophication Potential; POCP: Photochemical Ozone Creation Potential).

는 범주는 지구온난화 (GWP)와 광화학적 산화물생성 (POCP) 이었다 (Fig. 3). 이태리 쌀 생산체계에 대한 전과정평가에 서도 GWP와 $\mathrm{POCP}$ 의 기여도가 가장 높았고 기여도 또한 본 연구와 거의 유사하였다 (Blengini and Busto. 2009). 그러 나 Blengini and Busto (2009)의 연구에서는 부영양화 (EP) 의 기여도도 매우 높게 나타났다. 이러한 차이는 우리나라 농업분야 전과정평가 연구범위가 온실가스 배출로 제한되 어 정립되어 있기 때문이고, 질소와 인산에 의한 수계 배출 량 산정방법론이 부재하여 이들의 직접배출량 산정이 어렵 기 때문이다. 그러므로 지구온난화범주뿐 아니라 농업활동 에 의하여 영향을 많이 받는 부영양화 및 산성화 등의 범주 에 대한 보다 정밀한 전과정평가 방법론 정립이 연구되어야 할 것이다. 이 밖에 오존층파괴 $(\mathrm{ODP})$ 와 산성화 $(\mathrm{AP})$ 범주는 비료생산에 의한 영향이 가장 컸고, 자원결핍 $(\mathrm{ADP})$ 은 비료 생산과 연료생산에 기인하는 것으로 나타났다.

민감도 분석 및 온실가스 잠재량 산정 각 투입물량 을 5\% 씩 증가하거나 감소시켜 최대 -20 20\%까지 변화할 때 온실가스 배출량 변화에 대한 민감도 분석을 하였다. 에 너지 사용량 변화에 따른 민감도 분석결과 이산화탄소는 발 생량 변화를 보였으나, 메탄과 아산화질소의 발생량은 변화 가 거의 없었다. 이것은 벼 재배에서 농기계 연료 연소 및 전력

Table 7. Estimation of carbon footprint from conventional rice cultivation.

\begin{tabular}{lccc}
\hline \multicolumn{1}{c}{ Greenhouse gas } & Amount & Global warming potential & Amount $\left(\mathrm{CO}_{2}\right.$-eq. $)$ \\
\hline & $---\mathrm{kg} \mathrm{--}$ & & $---\mathrm{kg}$ co ceq. $_{2}---$ \\
$\mathrm{CO}_{2}$ & $3.29 \mathrm{E}-01$ & 1 & $3.29 \mathrm{E}-01$ \\
$\mathrm{CH}_{4}$ & $7.95 \mathrm{E}-02$ & 21 & $1.67 \mathrm{E}+00$ \\
$\mathrm{~N}_{2} \mathrm{O}$ & $6.79 \mathrm{E}-04$ & 310 & $2.10 \mathrm{E}-01$ \\
$\mathrm{HFCs}$ & $2.86 \mathrm{E}-08$ & 1300 & $3.71 \mathrm{E}-05$ \\
$\mathrm{SF}_{6}$ & $1.90 \mathrm{E}-09$ & 23900 & $4.55 \mathrm{E}-05$ \\
$\mathrm{CFC}-14$ & $1.64 \mathrm{E}-08$ & 6500 & $1.07 \mathrm{E}-04$ \\
\hline \multicolumn{2}{c}{ Total (Carbon footprint) } & & $2.21 \mathrm{E}+00$ \\
\hline
\end{tabular}




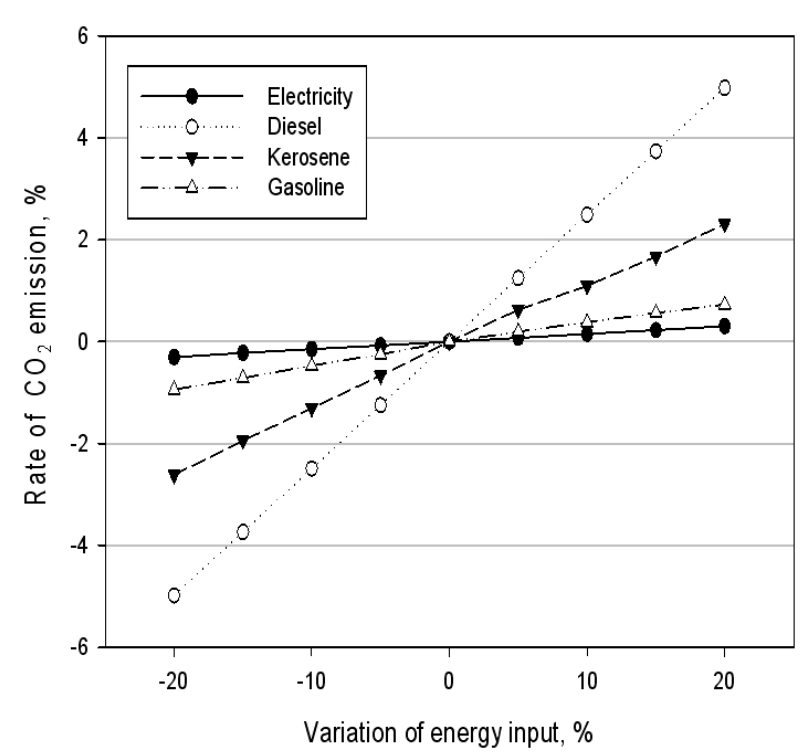

Fig. 4. Sensitivity analysis on variation of energy input.

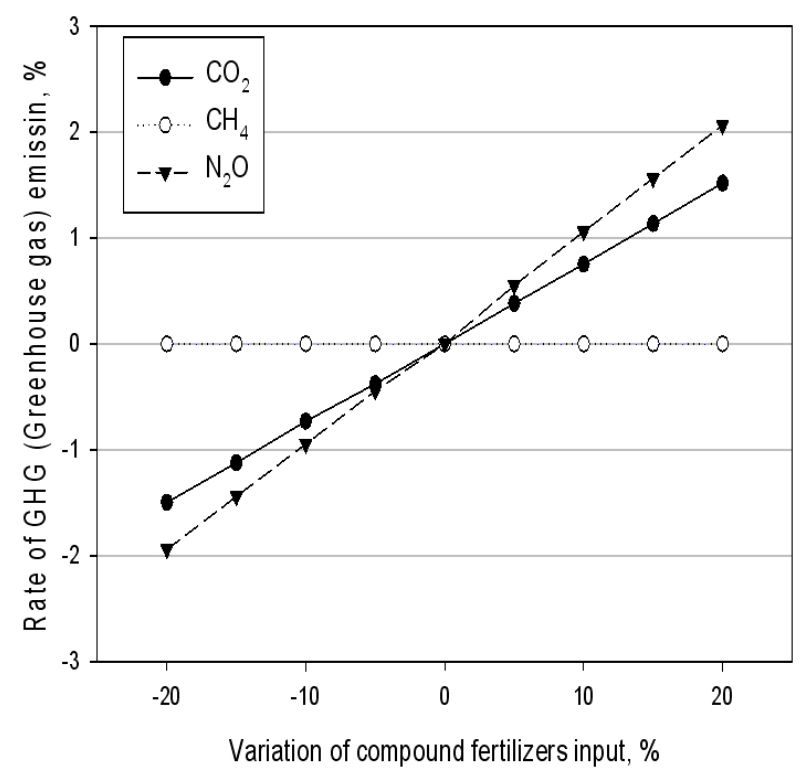

Fig. 5. Sensitivity analysis on variation of compound fertilizer input.

발생과정이 주로 이산화탄소 발생원이기 때문이다 (Kramer et al., 1999). 에너지원별로는 경유의 민감도가 가장 높았다 (Fig. 4). 분석결과 경유사용량을 $10 \%$ 줄였을 때 약 $2.5 \%$ 의 $\mathrm{CO}_{2}$ 감축 잠재량이 산정되었다. 그 다음으로 등유의 민감도 가 높게 나타났으며, 등유 사용량을 $10 \%$ 줄였을 때, $\mathrm{CO}_{2}$ 감 축 잠재량은 약 $1.4 \%$ 였다. 본 연구에서 수집된 경유사용처 는 경운 및 수확관련 농기계 사용이었으므로 무경운이나 농 기계의 효율적·경제적 운용에 대한 연구가 온실가스 저감 개선에 효과적일 것으로 판단되었다. Harada et al. (2007) 의 연구에 의하면 논토양에서 무경운으로 인한 경운기 무사 용으로 에너지소비 감소 효과를 볼 수 있으며, 이로 인한 온 실가스 저감효과가 약 $6 \%$ 로 보고되었다. 이와 더불어 무경

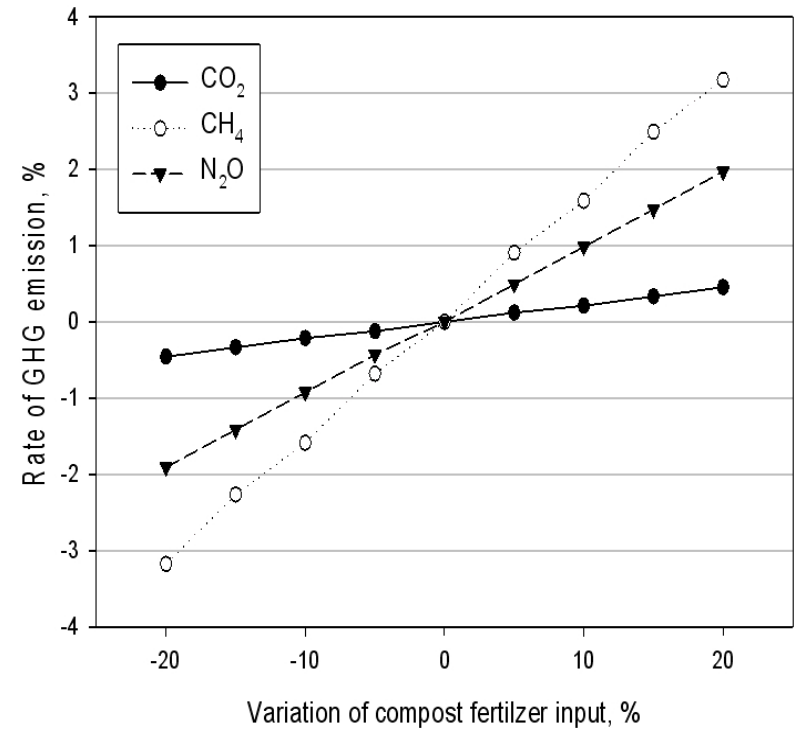

Fig. 6. Sensitivity analysis on variation of compost input.

운 농법은 토양구조를 보존하여 투수성을 높이는 효과가 있 다 (Hossain et al., 2000).

복비 사용량 증감에 따른 온실가스 발생변화는 Fig. 5와 같았다. 복비의 이산화탄소에 대한 민감도가 아산화질소 민 감도보다 약간 높았다. 이것은 복비 민감도가 질소질비료 시비에 의한 아산화질소 발생보다 복비를 생산하는 공정에 서 발생하는 이산화탄소 발생에 영향을 더 많이 받는 것으 로 분석되었다. 복비 시용량을 $10 \%$ 줄였을 때 $\mathrm{CO}_{2}$ 는 약 $1 \%$, $\mathrm{N}_{2} \mathrm{O}$ 는 약 $1.8 \%$ 의 감축잠재량이 산정되었다. 그러므로 토양 검정을 통한 정밀시비 등 합리적인 시비관리법은 염류집적 및 부영화 등의 환경부하 감소와 함께 탄소 배출을 감소할 수 있는 주요 요인이 될 수 있을 것이다.

퇴비의 경우 온실가스발생량 변화는 메탄이 가장 높았고, 다음이 아산화질소였고, 이산화탄소 발생 변화율이 가장 낮 았다 (Fig. 6). 탄소발생량의 민감도가 가장 높게 나타난 것 은 퇴비 생산 공정 중 부숙 과정에서 발생하는 메탄 발생이 매우 많으므로 이것이 민감도 분석에 가장 큰 영향을 주었 기 때문으로 판단되었다 (Amlinger et al., 2008). 민감도 분석결과 퇴비시용을 $10 \%$ 줄이면 약 $1.5 \%$ 의 메탄발생이 감 소하고, 아산화질소는 약 $1 \%$ 감소효과가 나타났다. 퇴비 메 탄발생량 저감은 비료생산과정에서의 발생을 억제하는 것 이 가장 직접적이고 효과적인 방법이므로 퇴비화 과정에서 유기물을 첨가하여 $\mathrm{C} / \mathrm{N}$ 율을 높이거나 산소공급, 톱밥첨가 등의 온실가스 저감 방법에 대한 연구가 필요할 것이다 (Ryu et al., 2011).

벼논의 물떼기 일수를 \pm 10 일까지 증감시킬 때 온실가스 변화량을 분석하였다 (Fig. 7). 물떼기 일수가 10일 증가하 면 메탄발생량이 약 $4.5 \%$ 감소되었다. 벼논 물관리는 메탄 발생 감소에 매우 효과적인 영농방법으로 보고되고 있으며 


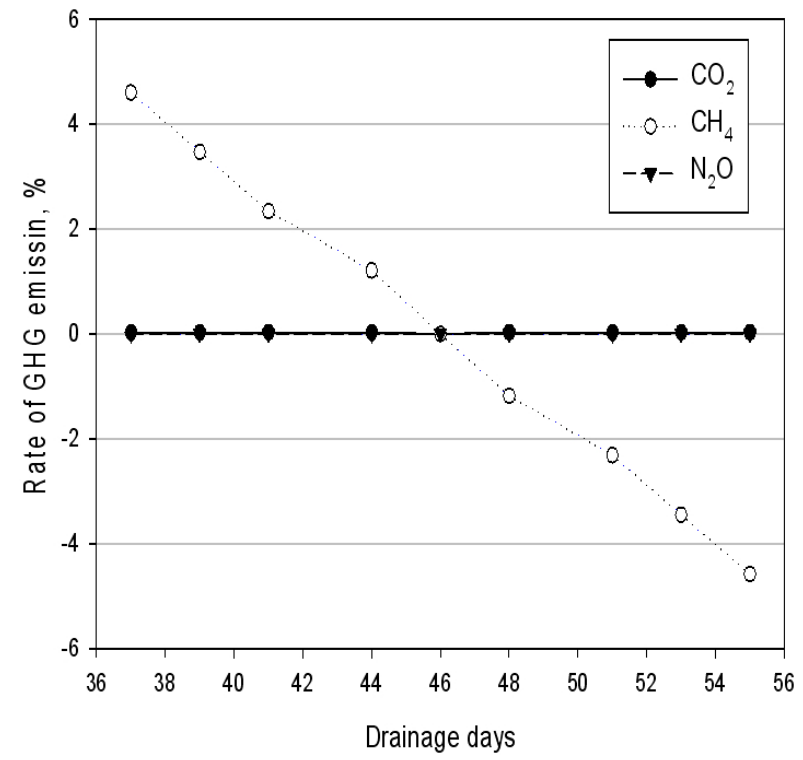

Fig. 7. Sensitivity analysis on variation of drainage days.

(Mishra et al., 1997; Rath, 1999), 중간낙수기간에는 메탄 이 50\%까지 감소된다는 연구 결과도 있다 (Kimura, 1992). 따라서 벼논에서 메탄발생은 탄소성적에 매우 중요한 기여 요인이므로 벼논 물떼기는 탄소저감을 위한 매우 중요한 영 농방법으로 판단되었다.

본 연구의 사례대상 농가들의 벼 재배방법에 대하여 민 감도 분석을 적용한 결과 투입량 변화에 따른 온실가스 감 소 효과가 가장 큰 요인은 벼논 물떼기 일수의 증가 및 경운 과 수확시 사용하는 농기계용 경유사용량의 감소였다. 그에 따라 중간낙수 및 무경운이 탄소배출 저감 영농법으로 제시 되었다. 그 밖에도 메탄발생 저감법으로 요소비료를 시용할 때, 질산화억제제를 사용하여 질소비료 효율을 높이고, 황 산염원료 형태의 질소질 비료시용으로 메탄발생량을 줄이 거나, 질소의 엽면시비 등이 추천되고 있다 (Majumdar, 2003). 또한 농기계 관리를 철저하게 하여 기계 및 설비의 기능을 향상하여 에너지 효율을 높이고, 윤작과 녹비작물 재배 등 의 작형 조절 등을 통한 비료 사용량 절감 등에 대한 연구도 필요할 것으로 판단된다.

\footnotetext{
Abstract

2011 2012년 2년간 전북 군산과 익산 지역의 관행농 벼 를 재배하는 농가를 대상으로 온실가스 배출량 산정을 위한 인벤토리 목록을 구축하였다. 2 년 누적 평균 데이터를 사용 하여 전과정평가를 수행하고, 탄소성적 산출 및 온실가스 배출의 주요인을 분석하였다. 분석된 온실가스 배출 주요인 자들을 대상으로 민감도 분석을 수행하여 온실가스 잠재량 을 산정하고, 대상지역 농가들이 적용할 수 있는 온실가스 저감 영농법을 제안하고자 하였다.
}

관행농 쌀 생산농가를 대상으로 전과정 목록분석을 수행한 결과 탄소성적은 쌀 $1 \mathrm{~kg}$ 생산을 기준으로 $2.21 \mathrm{~kg} \mathrm{CO}-\mathrm{eq}$. $\mathrm{kg}^{-1}$ 가 발생되었다. 온실가스 중 $\mathrm{CO}_{2}$ 배출량이 가장 많았으 나, 지구온난화 지수를 곱하여 이산화탄소 등가 $\left(\mathrm{CO}_{2}-\right.$ eq. $)$ 로 환산하면 벼 생산체계의 탄소성적에서 메탄발생 기여도 가 가장 컸다. 전체 $\mathrm{CO}_{2}$ 배출량 중 복비생산 공정에서 $37 \%$ 가 발생하였고, 단비생산으로 $10 \%$, 벼 재배과정 중 $40 \%$ 가 발생하였다. 벼 재배 중 $\mathrm{CO}_{2}$ 발생원은 농기계의 화석연료 사용에 의한 불완전 연소이다. $\mathrm{CH}_{4}$ 는 대부분 벼 재배 중에 발생되었으며, 벼논의 메탄 발생 요인은 혐기조건의 담수논 이다. $\mathrm{N}_{2} \mathrm{O}$ 은 대부분 벼 재배과정에서 배출되었고, 벼 재배 중 $\mathrm{N}_{2} \mathrm{O}$ 의 발생요인은 복비, 요소 비료, 퇴비 등의 비료시용 이었다.

에너지 사용량 변화에 따른 민감도 분석결과 에너지원 중 경유의 민감도가 가장 높았고, 경유사용량을 $10 \%$ 줄였을 때 약 $2.5 \%$ 의 $\mathrm{CO}_{2}$ 감축 잠재량이 산정되었다. 복비 시용량 을 $10 \%$ 줄였을 때 $\mathrm{CO}_{2}$ 는 약 $1 \%, \mathrm{~N}_{2} \mathrm{O}$ 는 약 $1.8 \%$ 의 감축잠재 량이 산정되었다. 퇴비시용을 $10 \%$ 줄이면 약 $1.5 \%$ 의 메탄발 생이 감소하고, 아산화질소는 약 $1 \%$ 감소효과가 나타났다. 물떼기 일수가 10 일 증가하면 메탄발생량이 약 $4.5 \%$ 감소되 었다. 투입량의 변화에 따른 온실가스 감소 효과가 가장 큰 요인은 벼논 물떼기 일수의 증가 및 경운과 수확시 사용하 는 농기계용 경유사용량 감소였다. 그에 따라 중간낙수 및 무경운 등이 탄소배출 저감 영농법으로 제시되었다.

\section{Acknowledgement}

본 연구는 농촌진흥청 국립농업과학원 농업과학기술 연 구개발사업 (과제번호: PJ00787403)의 지원에 의해 이루어 진 것입니다.

\section{References}

Ahn, S.J. 2005. Stochastic analysis for uncertainty of life cycle assessment with Monte-Carlo simulation, p.7-9, 29-30. M.S. University of Ajou, Korea.

Amlinger, F., S. Peyr, and C. Cuhls. 2008. Greenhouse gas emission from composting, and mechanical biological treatment. Waste Manage Research 26(1):47-60.

Bhatia, A., H. Pathak, N.P. Jain, K. Singh, and A.K. Singh. 2005. Global warming potential of manure amended soils under rice-wheat system in the Indo-Gangetic plains. Atmos. Environ. 39:6976-6984.

Blengini, G.A. and M. Busto. 2009. The life cycle of rice; LCA of alternative agri-food chain management system in Vercelli (Italy). Journal of Environmental Management 90:1512-1522. Harada, H., H. Kobayashi, and H. Shindo. 2007. Reduction in greenhouse gas emission by no-tilling rice cultivation in 
Hachirogata polder, nothern Japan: life cycle inventory analysis. Soil Science and Plant Nutrition 53:668-677.

Hossain, M.Z., K. Shibuya, and Saigusa. 2000: No-tillage transplanting system of rice with controlled availaility fertilizer in the nursery box. 1. Growth characteristics and yield of rice in three representative paddy soils. Tohoku J. Agric. Res. 50:71-86.

Jeong, H.C., G.Y. Kim, D.B. Lee, K.M. Shim, and K.K. Kang. 2011. Assessment of greenhpuse gases emission of agronomic sector between 1996 and 2006 IPCC guidelines. Korean J. Soil Sci. Fert. 44(6):1214-1219.

Jung, S.H., J.A. Park, J.H. Huh, and K.H. So. 2011. Estimation of greenhouse gas emission of complex fertilizers production system by using life cycle assessment. Korean. J. Soil. Sci. Fert. 44(2):256-262.

Kimura, M. 1992. Methane emission from paddy soils in Japan and Thailand, p. 43-79. In: Batjes, Bridges, E.M. (ed.), World inventory of soil emission potentials. WISE report 2, International Soil Reference and Information Centre, Wageningen.

Koga, N., H. Tsuruta, H. Tsuji, and H. Hakano. 2003. Fuel composition-derived $\mathrm{CO}_{2}$ emissions under conventional and reduced tillage cropping systems in northern Japan. J. of Agric., Ecos. and Environ. 99:213-219.

Kramer, K.J., H.C. Moll, S. Nonhebel, and H.C. Wilting. 1999. Greenhouse gas emissions related to Dutch food consumption Energy Policy. 27(4):203-216.

KWA (Korea Waste Association). 2007. Agricultural waste data. Korea Waste Association. Seoul, Korea.

Lehugera, S., B. Gabrielleb, P. Lavillec, M. Lambonid, B. Loubetd, and P. Cellierd. 2011. Predicting and mitigating the net greenhouse gas emissions of crop rotations in western Europe. Agricultural and Forest Meteorology 151:1654-1671

Majumdar, D. 2003. Methane and nitrous oxide emission from irrigated rice fields: Proposed mitigation strategies. Current Science 84(10):1317-1326.

MIFAFF (Ministry for Food, Agriculture, Forestry and Fisheres). 2004. A study on establishing effective management system for equipped agricultural input wastes. C2004-A1. Ministry for Food, Agriculture, Forestry and Fisheres. Seoul, Korea.

Mishra, S., A.K. Rath. T.K. Adhya. V.R. Rao, and N. Sethunathan. 1997. Effect of continuous and alternate water regimes on methane efflux from under greenhouse conditions. Biol. Fertil.
Soils 24:399-405.

MKE (Ministry of Knowledge Economy). Software program PASS v.4.1.3.

Mosier, A.R., A.D. Halvorson, G.A. Peterson, G.P. Robertson, and L. Sherrod. 2005. Measurement of net global warming potential in three agroecosystems. Nutr. Cycl. Agroecosys. 72:67-76.

Rath, A.K., B. swain, B. Ramakrishna, D. Panda, T.K. Adhya, V.R. Rao, and N. Sethunathan. 1999. Influence of fertilizer management and water regime on methane emission from rice fields. Agriculture, Ecosystems and Environment 76:99-107.

Robertson, G.P. and P.R. Grace. 2004. Greenhouse gas fluxes in tropical and temperate agriculture: The need for a full-cost accounting of global warming potentials. Environ., Dev. and Sustain. 6:51-63.

Ryu, J.H., K.H. Kim, G.Y. Kim, K.H. So, and K.K. Kang. 2011. Application of LCA on Lettuce Cropping System by Bottom-up Methodology in Protected Cultivation. Korean J. Soil Sci. Fert. 44(6):1195-1206.

Ryu, J.H., K.H. Kim, K.H. So, G.Z. Lee, G.Y. Kim, and D.B. Lee. 2011. LCA on lettuce cropping system by top-down method in protected cultivation. Korean J. Soil Sci. Fert. 44(6):1185-1194.

Ryu, J.H., S.C. Jung, G.Y. Kim, J.S. Lee and K.H. Kim. 2012. LCA (Life Cycle Assessment) for Evaluating Carbon Emission from Conventional Rice Cultivation System: Comparison of Top-down and Bottom-up Methodology 45(6):1143-1152.

Shin, S.C., and H.J. Park, 2011. A study on the feasibility of a policy mix in reducing GHG emission in Korea. Korea Environment Institute Report. 17-254 pp. 1.

Smith, P., D. Martino, Z. Cai, D. Gwary, H. Janzen, P. Kumar, B. McCarl, S. Ogle, F. O’Mara, C. Rice, B. Scholes, and O. Sirotenko. 2007. Agriculture. In Climate Change 2007: Mitigation. Contribution of Working Group III to the Fourth Assessment Report of the Intergovernmental Panel on Climate Change, [B. Metz, O.R. Davidson, P.R. Bosch, R. Dave, L.A. Meyer (eds)]. Cambridge University Press, Cambridge, United Kingdom and New York, NY, USA.

Van Zeijts, H., H. Leheman, and A.W. Sleeswijk. 1999. Fitting fertilisation in LCA: allocation to carops in a cropping plan. Journal of Cleaner Production 7:69-74. 